\title{
PENGARUH RISIKO BANK TERHADAP PROFITABILITAS BANK BPR DI KOTA DENPASAR
}

\author{
Kadek Nandari Cahya Pratiwi ${ }^{1}$ \\ Ni Putu Santi Suryantini² \\ ${ }^{1,2}$ Fakultas Ekonomi dan Bisnis Universitas Udayana (Unud), Bali, Indonesia \\ e-mail : nandaripratiwiyahoo.co.id
}

\begin{abstract}
ABSTRAK
Tujuan dari penelitian ini adalah untuk mengetahui pengaruh dari risiko likuiditas, risiko kredit, dan risiko operasional terhadap profitabilitas pada Bank Perkreditan Rakyat di Kota Denpasar pada periode 2013 - 2016. Penelitian ini menggunakan teknik analisis data yaitu regresi linier berganda. Sampel yang digunakan dalam penelitian ini adalah seluruh Bank Perkreditan Rakyat di Kota Denpasar pada periode 2013-2016 yaitu sebanyak 17 bank. Berdasarkan hasil analisis yang dilakukan dapat disimpulkan bahwa risiko likuiditas yang diwakili oleh LDR memiliki pengaruh positif signifikan terhadap profitabilitas, risiko kredit yang diwakili oleh NPL memiliki pengaruh negatif signifikan terhadap profitabilitas, dan risiko operasional yang diwakili oleh BOPO memiliki pengaruh negatif signifikan terhadap profitabilitas. Risiko likuiditas, risiko kredit, dan risiko operasional secara signifikan mempengaruhi profitabilitas sebesar 59,4\%, sedangkan sisanya sebesar 40,6\% dipengaruhi oleh faktor-faktor lain yang tidak dimasukkan kedalam model penelitian.
\end{abstract}

Kata kunci : $L D R, N P L, B O P O$, profitabilitas

\begin{abstract}
The aim of this research is to know the influence of the liquidity risk, credit risk, and operational risk towards the profitability in Bank Perkreditan Rakyat which is located in the city of Denpasar in the period 2013 - 2016. This research uses of data analysis techniques is multiple linear regression.The sample used in this research are all the Bank Perkreditan Rakyat in the city of Denpasar in the period 2013-2016 that is as much as 17 banks. Based on the results of the analysis carried out it can be concluded that liquidity risk is represented by the LDR have significant positive influence towards profitability, credit risk is represented by the NPL has a negative influence significantly to profitability, and operational risk is represented by the significant negative influence BOPO towards profitability.Liquidity risk, credit risk, and operational risk significantly affect the profitability of 59.4\%, while the rest of $40.6 \%$ of affected by other factors that are not incorporated into the model of research.
\end{abstract}

Keyword: LDR, NPL, BOPO, profitability 


\section{PENDAHULUAN}

Bank merupakan suatu lembaga keuangan yang mempunyai peranan yang penting dalam pembangunan perekonomian dari suatu negara yaitu sebagai perantara keuangan yang menghimpun dana dari masyarakat yang mempunyai kelebihan dana dan menyalurkannya pada masyarakat yang membutuhkan. Menurut Almazari (2014), kuatnya sektor perbankan dari suatu negara menyebabkan negara tersebut mampu untuk menghadapi guncangan negatif dan berkontribusi pada stabilitas dari sistem keuangannya.

Bank berdasarkan jenisnya dibedakan menjadi dua, yaitu Bank umum dan Bank Perkreditan Rakyat (BPR). Bank umum menurut Hendro dan Rahardja (2014:123) merupakan suatu badan usaha yang mempunyai tugas utama sebagai perantara keuangan yaitu dengan menyalurkan dana yang berasal dari pihak yang kelebihan dana (surplus) kepada pihak lainnya yang membutuhkan dana (defisit) pada waktu yang telah ditetapkan, sedangkan Bank Perkreditan Rakyat atau yang biasa disingkat BPR menurut Martono (2002:35) merupakan bank yang berfungsi untuk menerima simpanan berupa uang dan memberikan kredit jangka pendek untuk masyarakat di pedesaan.

BPR mempunyai peranan yang sangat penting untuk mendukung tingkat perekonomian masyarakat, sehingga keberadaan BPR sudah seharusnya mendapatkan perhatian yang lebih baik. Kinerja keuangan dari suatu BPR dapat diukur oleh masyarakat dan juga investor melalui analisis laporan keuangan. Analisis laporan keuangan tersebut dilakukan untuk mengetahui tingkat profitabilitas, tingkat risiko 
serta tingkat kesehatan dari bank tersebut (Capriani dan Dana, 2016). Bank yang merupakan suatu perusahaan jasa yang berorientasi kepada laba tentu harus menjaga tingkat profitabilitasnya dengan baik. Kinerja dari suatu bank dalam mengelola usahanya dapat dilihat dari laba atau profit yang didapatkannya dari kegiatan yang dijalankan oleh bank tersebut. Laba atau profit merupakan salah satu hal yang penting untuk dicapai oleh suatu perbankan agar perbankan mengetahui apakah usahanya telah dikerjakan secara efisien (Ramadanti dan Meiranto, 2015). Sudiyanto dan Fatmawati (2013) menyatakan profitabilitas bank merupakan kemampuan bank dalam menghasilkan laba dan merupakan salah satu aspek yang dapat digunakan sebagai tolok ukur untuk menilai keberhasilan bank dalam menjalankan kegiatannya. Menurut Wiagustini (2010:76), salah satu tujuan dari bank adalah untuk memperoleh profitabilitas yang maksimal sehingga bank tersebut dapat mengoptimalkan kegiatan operasionalnya. Bagi pemilik, penyimpan, pemerintah dan masyarakat profitabilitas dari bank sangat penting, sehingga bank perlu menjaga profitabilitasnya agar bank tersebut tetap stabil atau bahkan meningkat (Prasetyo dan Darmayanti, 2015).

Penelitian ini menggunakan Return On Assets (ROA) yang merupakan perbandingan dari laba sebelum pajak terhadap total aset untuk mewakili profitabilitas, karena ROA memfokuskan kemampuan perusahaan untuk memperoleh laba dalam operasi perusahaan (Putri, 2013). Menurut Capriani dan Dana (2016), semakin besar tingkat ROA dari suatu bank maka semakin besar profitabilitas yang diperoleh sehingga kinerja dari bank tersebut akan semakin baik. 


\section{Tabel 1}

Tingkat LDR, NPL, BOPO dan ROA pada BPR di Kota Denpasar pada Tahun 2013-2016

\begin{tabular}{ccccc}
\hline Tahun & LDR & NPL & BOPO & ROA \\
\hline 2013 & $78,79 \%$ & $0,94 \%$ & $72,36 \%$ & $3,38 \%$ \\
2014 & $76,04 \%$ & $1,32 \%$ & $70,72 \%$ & $3,65 \%$ \\
2015 & $84,29 \%$ & $1,65 \%$ & $71,85 \%$ & $3,53 \%$ \\
2016 & $67,14 \%$ & $3,08 \%$ & $73,66 \%$ & $3,00 \%$ \\
\hline \multicolumn{4}{l}{ Sumber: $w w w . b i .90 . i d($ data diolah, 2017$)$}
\end{tabular}

Sumber: www.bi.go.id (data diolah, 2017)

Pada Tabel 1 dapat dilihat fenomena yang terjadi pada Bank Perkreditan Rakyat di Kota Denpasar pada tahun 2013-2016. Terjadi fluktuasi tingkat LDR, NPL, BOPO, dan ROA pada empat tahun periode tersebut. Fenomena inilah yang mendorong peneliti untuk menggunakan Bank Perkreditan Rakyat di Kota Denpasar sebagai lokasi penelitian. Peneliti ingin mengetahui apakah ada pengaruh dari risiko perbankan yaitu risiko likuiditas, risiko kredit, dan risiko operasional terhadap profitabilitas yang terjadi pada BPR di Kota Denpasar selama periode 2013-2016.

Menurut Martono (2002:86), setiap jenis usaha pasti akan mengalami berbagai risiko, begitu juga pada bisnis perbankan. Penelitian ini menggunakan beberapa risiko yang dapat memengaruhi profitabilitas suatu bank, yaitu risiko likuiditas, risiko kredit, dan risiko operasional. Hal ini disebabkan karena likuiditas, kredit, dan kegiatan operasional dari suatu bank cenderung mempengaruhi terjadinya risiko terhadap tingkat profitabilitas bank tersebut.

Likuiditas merupakan salah satu faktor yang mempengaruhi profitabilitas dari suatu bank. Ramadanti dan Meiranto (2015) menyatakan apabila suatu bank tidak dapat 
menyediakan dana kepada deposan ketika deposan tersebut melakukan penarikan dana maka akan menimbulkan terjadinya risiko likuiditas. Menurut peraturan Bank Indonesia No 11/25/PBI/2009, risiko likuiditas merupakan risiko yang terjadi akibat bank tidak mampu untuk memenuhi kewajibannya yang telah jatuh tempo kepada nasabah. Risiko likuiditas dalam penelitian ini diwakili oleh Loan to Deposit Ratio (LDR) yang merupakan rasio yang digunakan untuk mengukur kemampuan dari suatu bank dalam menyalurkan kredit dari dana pihak ketiga yang terhimpun dalam bank tersebut (Ramadanti dan Meiranto, 2015).

Terdapat beberapa penelitian yang menguji pengaruh risiko likuiditas terhadap profitabilitas. Menurut Dawood (2014), risiko likuiditas yang diwakili oleh LDR berpengaruh negatif terhadap profitabilitas, hasil penelitian tersebut serupa dengan penelitian yang dilakukan Dahiyat (2016). Abdullah and Jahan (2014) serta Alkhazaleh and Almsafir (2014) menyatakan tidak ada pengaruh yang signifikan dari risiko likuiditas terhadap profitabilitas. Hal tersebut berlawanan dengan penelitian yang dilakukan oleh Jumono et al. (2015), Rahman et al. (2015), Prasetyo dan Darmayanti (2015), Abel and Roux (2016), Capriani dan Dana (2016) yang menemukan bahwa risiko likuiditas bank berpengaruh positif signifikan terhadap profitabilitas.

Hal yang terpenting dari manajemen perbankan adalah bagaimana cara dari suatu bank untuk mengelola dana yang tersedia. Sebagian besar dana dari sumber dana bank dialokasikan untuk kredit, sehingga pendapatan bank yang terbesar berasal dari bunga atas kredit-kredit yang dinikmati oleh para nasabah (Abdullah, 2012:161). Selain menjadi sumber pendapatan dan keuntungan, kegiatan penyaluran kredit juga menjadi 
penyebab suatu bank mengalami risiko kredit. Menurut peraturan Bank Indonesia No 11/25/PBI/2009, risiko kredit adalah risiko yang terjadi akibat debitur dan/atau pihak lain tidak mampu untuk memenuhi kewajibannya yang telah jatuh tempo kepada bank. Risiko kredit dalam penelitian ini diwakili oleh Non Performing Loan (NPL), yaitu rasio yang digunakan untuk mengukur kemampuan dari suatu bank dalam menangani risiko kegagalan pengembalian kredit oleh debitur. Putri (2013) menyatakan bahwa tingkat NPL yang tinggi menunjukkan buruknya kualitas kredit bank sehingga menyebabkan besarnya jumlah kredit bermasalah pada bank tersebut. Besarnya kredit bermasalah pada suatu bank menyebabkan bank tersebut harus menanggung kerugian dalam kegiatan operasionalnya yang akan menurunkan laba yang diperoleh bank tersebut.

Penelitian mengenai pengaruh risiko kredit yang diwakili oleh NPL terhadap profitabilitas yang dilakukan oleh Rahman et al. (2015), Prasetyo dan Darmayanti (2015), Abel and Roux (2016), Bhattarai (2016), Herlina dkk. (2016), Suryanto (2017) menemukan hasil bahwa risiko kredit memiliki pengaruh negatif signifikan terhadap profitabilitas, sementara penelitian Ogboi and Unuafe (2013), Jumono et al. (2015) menemukan hasil bahwa risiko kredit memiliki pengaruh negatif namun tidak signifikan terhadap profitabilitas. Penelitian yang dilakukan oleh Jha and Hui (2012) dan Buchory (2015) berlawanan dengan hasil penelitian lainnya dengan hasil risiko kredit berpengaruh positif signifikan terhadap profitabilitas.

Menurut Prasetyo dan Darmayanti (2015), untuk menghadapi berbagai persaingan dan tuntutan dari para konsumen, pengelolaan bank secara efisien 
merupakan salah satu faktor yang sangat penting bagi bank untuk menjaga kelangsungan operasionalnya dalam jangka waktu lama. Efisiensi operasional bank merupakan kemampuan dari suatu bank dalam mengelola input menjadi output secara efisien. Triandaru dan Budisantoso (2009:107) menyatakan dalam melakukan kegiatan operasionalnya, setiap bank pasti mengalami risiko seperti terjadinya kerugian akibat perubahan struktur biaya operasional bank atau bank gagal meluncurkan produkproduk perbankan baru kepada masyarakat. Menurut Arthesa dan Handiman (2009:201), risiko operasional merupakan risiko yang terjadi karena proses internal bank yang kurang berfungsi, human error, kegagalan sistem teknologi, atau akibat permasalahan eksternal. Risiko operasional dalam penelitian ini diwakili oleh Biaya Operasional terhadap Pendapatan Operasional (BOPO) yaitu rasio antara biaya operasional dibandingkan dengan pendapatan operasional. Oktaviantari dan Wiagustini (2013) menyatakan bank yang memiliki tingkat BOPO yang tinggi menunjukkan kegiatan operasional dari bank tersebut tidak dijalankan dengan efisien sehingga memungkinkan terjadinya risiko operasional. Tingginya BOPO menunjukkan bahwa beban operasional bank melebihi pendapatannya sehingga akan menurunkan laba bank tersebut. Sebaliknya, rendahnya tingkat BOPO menunjukkan bahwa bank sudah mengelola biaya operasionalnya dengan efisien sehingga laba yang diperoleh bank tersebut meningkat.

Penelitian yang dilakukan Buchory (2015) menunjukkan risiko operasional yang diwakili oleh BOPO memiliki pengaruh negatif dan signifikan terhadap profitabilitas, hal tersebut sejalan dengan penelitian dari Prasetyo dan Darmayanti (2015), Dewi dkk. 
(2015), Capriani dan Dana (2016). Hasil yang berbeda ditemukan dalam penelitian yang dilakukan oleh Pamularsih (2015) dan Syafi'I (2016) yaitu risiko operasional (BOPO) berpengaruh secara positif dan signifikan terhadap profitbilitas.

Perbedaan pendapat yang terdapat pada penelitian-penelitian yang telah dilakukan sebelumnya, menunjukkan bahwa dalam penelitian ini terdapat research gap yang perlu dikaji kembali, sehingga perlu dilakukan penelitian kembali untuk memperjelas temuan selanjutnya.

Berdasarkan latar belakang masalah yang telah diuraikan diatas, maka yang menjadi rumusan masalah dari penelitian ini adalah sebagai berikut: 1) Apakah risiko likuiditas berpengaruh terhadap profitabilitas Bank BPR? 2) Apakah risiko kredit berpengaruh terhadap profitabilitas Bank BPR? 3) Apakah risiko operasional berpengaruh terhadap profitabilitas Bank BPR?

Berdasarkan rumusan masalah diatas, maka yang menjadi tujuan dari penelitian ini adalah: 1) Untuk mengetahui pengaruh risiko likuiditas terhadap profitabilitas pada Bank BPR 2) Untuk mengetahui pengaruh risiko kredit terhadap profitabilitas pada Bank BPR 3) Untuk mengetahui pengaruh risiko operasional terhadap profitabilitas pada Bank BPR.

Adapun manfaat teoritis dari penelitian ini adalah untuk dapat memberi kontribusi dalam memperkuat temuan empiris mengenai risiko perbankan yaitu risiko likuiditas, risiko kredit, dan risiko operasional terhadap profitabilitas. Manfaat praktis dari penelitian ini adalah untuk secara praktis mampu menjadi bahan pertimbangan bagi BPR di Kota Denpasar dalam pengambilan keputusan yang berhubungan dengan 
upaya untuk meningkatkan profitabilitasnya serta dapat membantu praktisi dan emitem dalam memberikan informasi mengenai risiko-risiko yang dapat terjadi pada kegiatan operasional perbankan, sehingga dapat memperkecil terjadinya kerugian akibat risikorisiko bank tersebut.

Menurut Martono (2002:27), risiko likuiditas merupakan suatu risiko yang mungkin dihadapi oleh sebuah bank untuk memenuhi kebutuhan likuiditas dari bank tersebut guna memenuhi permintaan kredit dan penarikan dana oleh nasabah pada suatu waktu. Masalah yang mungkin akan dihadapi oleh bank adalah bank tidak mampu mengetahui secara pasti kapan dan berapa jumlah dana yang akan diambil oleh para nasabah. Oleh karena itu, dalam mengelola suatu bank, memperkirakan kebutuhan likuiditas merupakan masalah bank yang cukup rumit.

Risiko likuiditas dalam penelitian ini diwakilkan oleh LDR (Loan to Deposit Ratio). Tingginya tingkat LDR suatu bank menunjukkan bahwa likuiditas dari bank tersebut rendah sehingga akan menyebabkan terjadinya risiko likuiditas. Tingkat LDR yang tinggi terjadi karena jumlah dana yang diperlukan untuk pembiayaan atau pemberian kredit semakin besar sehingga pendapatan bunga dari hasil pembiayaan atau kredit tersebut juga meningkat. Meningkatnya jumlah bunga dari hasil pembiayaan atau kredit tersebut akan menyebabkan profitabilitas bank juga meningkat (Nugraheni dan Alam, 2014). Penelitian ini sesuai dengan penelitian yang telah dilakukan oleh Jumono et al. (2015), Prasetyo dan Darmayanti (2015), dan Abel and Roux (2016) yang menemukan bahwa risiko likuiditas berpengaruh positif dan signifikan terhadap 
profitabilitas (ROA) bank. Berdasarkan uraian tersebut dapat ditarik hipotesis sebagai berikut :

$\mathrm{H}_{1}$ : Risiko Likuiditas memiliki pengaruh positif signifikan terhadap profitabilitas.

Pemberian kredit yang dilakukan oleh bank tentu tidak akan lepas dari risiko yang harus dihadapi. Martono (2002:26) menyatakan bahwa risiko kredit merupakan suatu risiko yang terjadi akibat ketidakmampuan nasabah untuk mengembalikan pinjaman beserta bunga yang diterima dari bank sesuai dengan jangka waktu yang telah ditentukan sebelumnya. Risiko kredit di penelitian ini diwakilkan oleh NPL (Non Performing Loan). Tingginya tingkat NPL dalam suatu bank menunjukkan jumlah kredit bermasalah pada bank tersebut mengalami peningkatan sehingga akan memperburuk kualitas kreditnya sehingga akan menyebabkan terjadinya risiko kredit. Menurunnya kualitas kredit menyebabkan bank harus menanggung kerugian pada kegiatan operasionalnya yang akan berpengaruh terhadap penurunan laba yang didapatkan bank tersebut. Pendapat ini didukung oleh hasil dari penelitian yang telah dilakukan oleh, Bhattarai (2016), dan Suryanto (2017) menemukan hasil bahwa risiko kredit memiliki pengaruh negatif dan signifikan terhadap profitabilitas bank. Berdasarkan uraian tersebut dapat ditarik hipotesis sebagai berikut :

$\mathrm{H}_{2}$ : Risiko Kredit memiliki pengaruh negatif signifikan terhadap profitabilitas.

Penurunan keuntungan yang dipengaruhi oleh struktur biaya operasional bank dan kegagalan atas jasa-jasa dan produk-produk baru yang diperkenalkan dapat menyebabkan terjadinya risiko operasional. Menurut Martono (2002:27), risiko operasional atau operational risk merupakan suatu risiko dari ketidakpastian mengenai 
usaha bank yang bersangkutan. Risiko operasional dalam penelitian ini diwakilkan oleh rasio BOPO (Biaya Operasional terhadap Pendapatan Operasional). Semakin tinggi tingkat persentase BOPO menunjukkan rendahnya kemampuan bank dalam menekan biaya operasionalnya sehingga menyebabkan terjadinya biaya yang tidak efisien. Ketidakefisienan tersebut menyebabkan alokasi biaya yang lebih tinggi sehingga dapat menurunkan pendapatan suatu bank. Semakin kecil persentase BOPO, maka semakin efisien biaya operasional yang dikeluarkan bank sehingga semakin kecil kemungkinan suatu bank akan menghadapi kondisi bermasalah (Pamularsih, 2015). Penelitian ini sesuai dengan penelitian yang telah dilakukan oleh Buchory (2015) yang menunjukkan risiko operasional memiliki pengaruh negatif dan signifikan terhadap profitabilitas, penelitian tersebut sejalan dengan penelitian dari Dewi dkk. (2015), dan Capriani dan Dana (2016). Berdasarkan uraian tersebut dapat ditarik hipotesis sebagai berikut :

$\mathrm{H}_{3}$ : Risiko Operasional memiliki pengaruh negatif signifikan terhadap profitabilitas.

Untuk memperjelas arah dari penelitian ini maka disajikan kerangka konseptual sebagai berikut.

\section{Variabel Independen}

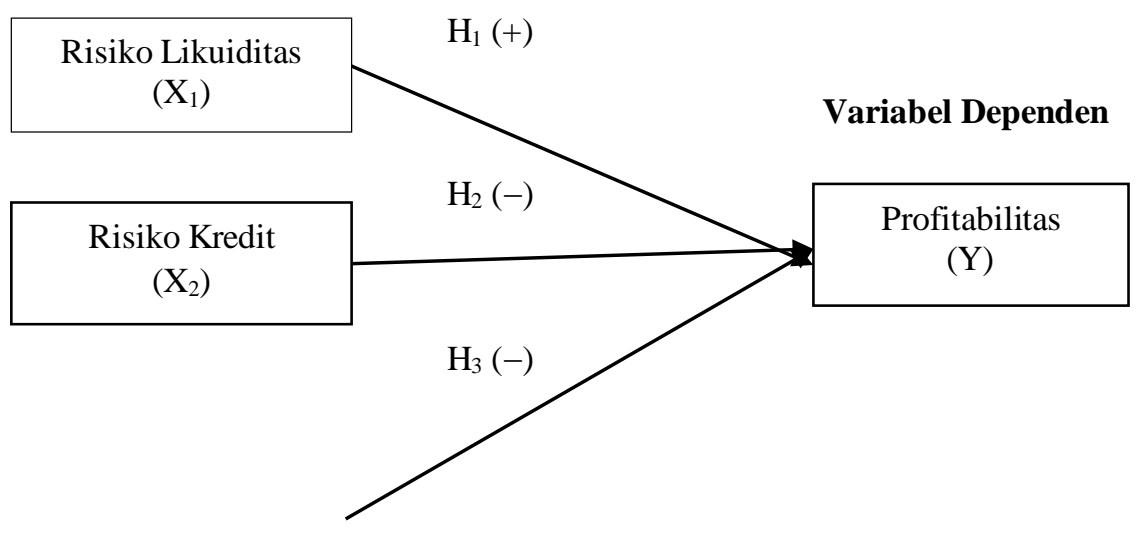


Risiko Operasional

$\left(\mathrm{X}_{3}\right)$

Gambar 1. Kerangka Konseptual Penelitian

\section{METODE PENELITIAN}

Penelitian ini bersifat asosiatif yang menguji pengaruh risiko likuiditas, risiko kredit, dan risiko operasional terhadap profitabilitas. Lokasi penelitian dilakukan di seluruh Bank Perkreditan Rakyat (BPR) Kota Denpasar dengan mengambil data pada laporan keuangan BPR yang dipublikasikan oleh Bank Indonesia. Obyek dari penelitian ini adalah tingkat profitabilitas yang terdapat pada BPR di Kota Denpasar periode 2013-2016.

Penelitian ini dilakukan untuk menguji pengaruh risiko bank terhadap profitabilitas pada BPR di Kota Denpasar pada periode 2013-2016. Terdapat empat variabel yang dianalisis dalam penelitian ini, yaitu satu variabel dependen yaitu profitabilitas dan tiga variabel independen yaitu risiko likuiditas, risiko kredit, dan risiko operasional.

Profitabilitas dalam penelitian ini diukur menggunakan Return on Assets (ROA) yang membandingkan laba sebelum pajak dengan rata-rata total aset yang dimiliki oleh BPR di Kota Denpasar pada tahun 2013-2016. Menurut Triandaru dan Budisantoso (2009:62), Return on Assets (ROA) dapat dirumuskan sebagai berikut:

$\mathrm{ROA}=\left(\frac{\text { Laba Sebelum Pajak }}{\text { Rata-Rata Total Aset }}\right) \times 100 \%$

Risiko likuiditas dalam penelitian ini diukur menggunakan Loan to Deposit Ratio (LDR) yang membandingkan kredit dengan dana pihak ketiga BPR di Kota Denpasar pada 
tahun 2013-2016. Menurut Triandaru dan Budisantoso (2009:64), LDR dapat dirumuskan sebagai berikut:

$\mathrm{LDR}=\left(\frac{\text { Kredit }}{\text { Dana Pihak Ketiga }}\right) \times 100 \%$

Risiko kredit dalam penelitian ini diukur menggunakan Non Performing Loan (NPL) yang membandingkan kualitas produktif bermasalah dengan aktiva produktif dari BPR di Kota Denpasar pada tahun 2013-2016. Menurut Pamularsih (2015) NPL dapat dirumuskan sebagai berikut:

$\mathrm{NPL}=\frac{\text { Kualitas Produktif Bermasalah }}{\text { Aktiva Produktif }} \times 100 \%$

Risiko operasional dalam penelitian ini diukur menggunakan Biaya Operasional terhadap Pendapatan Operasional (BOPO) yang membandingkan total beban operasional dengan total pendapatan operasional dari BPR di Kota Denpasar pada tahun 2013-2016. Menurut Budisantoso dan Nuritomo (2015:86) BOPO dapat dirumuskan sebagai berikut:

$\mathrm{BOPO}=\left(\frac{\text { Total Beban Operasional }}{\text { Total Pendapatan Operasional }}\right) \times 100 \%$

Data yang digunakan dalam penelitian ini adalah data kualitatif dan kuantitatif. sumber data yang digunakan dalam penelitan ini adalah data sekunder yang didapatkan dari laporan keuangan tahunan BPR di Kota Denpasar pada periode 2013-2016 yang dipublikasikan oleh Bank Indonesia melalui dari website resmi Bank Indonesia yaitu www.bi.go.id.

Populasi yang dipakai pada penelitian ini adalah BPR di Kota Denpasar pada periode 2013-2016. Penelitian ini menggunakan metode sampling jenuh sebagai 
metode penentuan sampel. Sampel yang digunakan dalam penelitian ini adalah seluruh Bank Perkreditan Rakyat di Kota Denpasar periode 2013-2016 yaitu sebanyak 17 bank.

\section{Tabel 2}

\section{Daftar Sampel Penelitian Periode 2013-2016}

\begin{tabular}{cl}
\hline No. & \multicolumn{1}{c}{ Nama BPR } \\
\hline 1 & PT. BPR Duta Bali d/h Martabat Buana \\
2 & PT. BPR Pedungan \\
3 & PT. BPR Bank Desa Sanur \\
4 & PT. BPR Sari Nadi \\
5 & PT. BPR Sari Sedana \\
6 & PT. BPR Pasar Umum \\
7 & PT. BPR Pande Artha Dewata \\
8 & PT. BPR Pusaka \\
9 & PT. BPR Tata Anjungsari \\
10 & PT. BPR Picu Manunggal Sejahtera \\
11 & PT. BPR Padma \\
12 & PT. BPR Bali Dananiaga \\
13 & PT. BPR Legian \\
14 & PT. BPR Antenk \\
15 & PT. BPR Hari Depan \\
16 & PT. BPR Partha Kencana Tohpati \\
17 & PT. BPR Hoki \\
\hline Sumber: www.bi.go.id (data diolah, 2017)
\end{tabular}

Teknik analisis data yang digunakan dalam penelitian ini adalah teknik analisis regresi linier berganda sebagai pengolahan data, teknik ini digunakan sebagai estimasi nilai variabel secara dependen (terikat) dengan menggunakan variabel independen (bebas) lebih dari satu. Pengerjaan pengolahan data pada analisis regresi linier berganda ini akan dibantu dengan program SPSS.

Untuk menguji model tersebut maka digunakan analisa regresi linier berganda dengan rumus yaitu (Ghozali, 2011:97):

$\mathrm{Y}=\alpha+\beta_{1} X_{1}+\beta_{2} X_{2}+\beta_{3} X_{3}+\mathrm{e}$

Keterangan :

$\mathrm{Y}=$ Profitabilitas $(R O A)$ 
$\alpha=$ Konstanta

$\beta_{1}=$ Koefisien regresi dari Risiko Likuiditas $\left(X_{1}\right)$

$\beta_{2}=$ Koefisien regresi dari Risiko Kredit $\left(X_{2}\right)$

$\beta_{3}=$ Koefisien regresi dari Risiko Operasional $\left(X_{3}\right)$

$\mathrm{X}_{1}=$ Risiko Likuiditas

$\mathrm{X}_{2}=$ Risiko Kredit

$\mathrm{X}_{3}=$ Risiko Operasional

$e=$ Standar error

\section{HASIL DAN PEMBAHASAN}

\section{Tabel 3}

Statistik Deskriptif Sampel Penelitian

\begin{tabular}{lccccc}
\hline & & & & & $\begin{array}{c}\text { Std. } \\
\text { Deviation }\end{array}$ \\
\hline LDR & 68 & 10 & 104 & 79.79 & 13.002 \\
NPL & 68 & 0 & 48 & 5.66 & 7.194 \\
BOPO & 68 & 46 & 214 & 85.18 & 28.829 \\
ROA & 68 & -24 & 12 & 3.01 & 5.239 \\
Valid N & 68 & & & & \\
(listwise) & & & & & \\
\hline
\end{tabular}

Sumber: Data Diolah, 2017

Tabel 3 menunjukkan bahwa rata-rata LDR di BPR Kota Denpasar sebesar 79,79 persen dengan nilai LDR tertinggi sebesar 104 persen yang terjadi pada tahun 2015 dan nilai LDR terendah yang terjadi pada tahun 2016 yaitu sebesar 10 persen. Rata-rata NPL di BPR Kota Denpasar sebesar 5,66 persen dengan nilai NPL tertinggi sebesar 48 persen pada tahun 2015 dan nilai NPL terendah sebesar 0 persen yang terjadi pada tahun 2013 sampai dengan 2016. Rata-rata BOPO di BPR Kota Denpasar sebesar 85,18 persen dengan nilai BOPO tertinggi sebesar 214 persen pada tahun 2015 dan nilai BOPO terendah sebesar 46 persen yang terjadi pada tahun 2015 dan 2016. Rata-rata 
Kadek Nandari Cahya Pratiwi, Pengaruh risiko bank terhadap profitabilitas...]

ROA di BPR Kota Denpasar sebesar 3,01 persen dengan nilai ROA tertinggi terjadi pada tahun 2014 dan 2015 yaitu sebesar 12 persen dan nilai ROA terendah sebesar -24 persen terjadi pada tahun 2014.

Tabel 4

Uji Normalitas

\begin{tabular}{cc}
\hline & Unstandardized Residual \\
\hline $\mathrm{N}$ & 68 \\
Asymp. Sig. (2-tailed) & 0,175 \\
\hline Sumber: Data Diolah, 2017 &
\end{tabular}

Tabel 4 menunjukkan bahwa nilai Asymp. Sig. (2-tailed) dari penelitian ini adalah 0,175. Hasil tersebut lebih besar dibandingkan taraf signifikansi yaitu sebesar 0,05 sehingga dapat disimpulkan bahwa data yang dipergunakan berdistribusi normal atau telah memenuhi syarat normalitas.

Tabel 5

Uji Autokorelasi

\begin{tabular}{|c|c|c|c|c|c|}
\hline Model & $\boldsymbol{R}$ & R Square & $\begin{array}{c}\text { Adjusted } R \\
\text { Square }\end{array}$ & $\begin{array}{l}\text { Std. Error of the } \\
\text { Estimate }\end{array}$ & $\begin{array}{l}\text { Durbin- } \\
\text { Watson }\end{array}$ \\
\hline 1 &, $783^{\mathrm{a}}$ & 612 & ,594 & ,64254301 & 2,019 \\
\hline
\end{tabular}

Sumber: Data Diolah, 2017

Tabel 5 menunjukkan bahwa nilai Durbin Watson dalam penelitian ini adalah sebesar 2,019. Penelitian ini menggunakan 68 sampel dan 3 variabel bebas sehingga 
nilai $\mathrm{d}_{\mathrm{U}}$ adalah 1,700 dan nilai 4-d $\mathrm{d}_{\mathrm{U}}$ adalah 2,300. Oleh karena nilai $\mathrm{d}_{\mathrm{U}}<\mathrm{DW}<4-\mathrm{d}_{\mathrm{U}}$ atau 1,700<2,019<2,300, maka dapat disimpulkan bahwa tidak ada autokorelasi dalam penelitian ini.

Tabel 6

Uji Multikolinieritas

\begin{tabular}{ccc}
\hline & \multicolumn{2}{c}{ Colinierity Statistic } \\
\cline { 2 - 3 } Model & Tolerance & VIF \\
\cline { 2 - 3 } & & \\
\hline LDR & 0,825 & 1,212 \\
NPL & 0.652 & 1,533 \\
BOPO & 0,722 & 1,384 \\
\hline
\end{tabular}

Sumber: Data Diolah, 2017

Tabel 6 menunjukkan bahwa koefisien Tolerance semua variabel lebih besar dari 0,10 dan nilai VIF yang lebih kecil dari 10 . Hasil tersebut menunjukkan bahwa tidak terdapat gejala multikolinieritas dalam model regresi yang dibuat.

Tabel 7

Uji Heteroskedastisitas

\begin{tabular}{ccc}
\hline Model & Sig. & Keterangan \\
\hline LDR & 0,272 & Lolos Uji \\
NPL & 0,552 & Lolos Uji \\
BOPO & 0,481 & Lolos Uji \\
\hline Sumber: Data Diolah, 2017 &
\end{tabular}


Tabel 7 menunjukkan nilai signifikansi dari masing-masing variabel bebas lebih besar dari 0,05, sehingga dapat disimpulkan bahwa model regresi tersebut bebas dari gejala heteroskedastisitas.

Tabel 8

Uji Analisis Regresi Linier Berganda

\begin{tabular}{cccccc}
\hline \multirow{2}{*}{ Model } & \multicolumn{2}{c}{ Unstandardized Coefficients } & $\begin{array}{c}\text { Standardized } \\
\text { Coefficients }\end{array}$ & \multirow{2}{*}{$\boldsymbol{T}$} & Sig. \\
\cline { 2 - 4 } & $\boldsymbol{B}$ & Std. Error & Beta & & \\
\hline (Constant) & 0,026 & 0,078 & & 0,338 & 0,736 \\
LDR & 0,364 & 0,087 & 0,36 & 4,202 & 0,000 \\
NPL & $-0,415$ & 0,096 & $-0,417$ & $-4,33$ & 0,000 \\
BOPO & $-0,219$ & 0,093 & $-0,217$ & $-2,367$ & 0,021 \\
R & 0,783 & & & & \\
$\mathrm{R}^{2}$ & 0,612 & & & & \\
Adjusted R ${ }^{2}$ & 0,594 & & & & \\
F hitung & 33,707 & & & & \\
Sig. F & 0,000 & & & & \\
\hline Sumber: Data Diolah, 2017 &
\end{tabular}

Berdasarkan Tabel 8 dapat diperoleh persamaan regresi linier berganda sebagai berikut:

$\mathrm{Y}=0,026+0,364 \mathrm{X}_{1}-0,415 \mathrm{X}_{2}-0,219 \mathrm{X}_{3}$

Hasil perhitungan regresi diatas menyatakan bahwa nilai konstanta sebesar 0,026. Hal tersebut menunjukkan apabila variabel risiko likuiditas $\left(\mathrm{X}_{1}\right)$, risiko kredit $\left(\mathrm{X}_{2}\right)$, dan risiko operasional $\left(\mathrm{X}_{3}\right)$ sama dengan nol, maka besarnya variabel dependen profitabilitas (Y) akan sebesar 0,026. Variabel risiko likuiditas ( $\mathrm{X}_{1}$ ) mempunyai koefisien 0,364 dengan arah positif. Hal ini menunjukkan apabila tingkat risiko likuiditas mengalami kenaikan sebesar 1 persen sementara variabel independen lainnya 
konstan maka profitabilitas akan mengalami peningkatan sebesar 0,364 persen. Variabel risiko kredit $\left(\mathrm{X}_{2}\right)$ mempunyai koefisien $-0,415$ dengan arah negatif. Hal ini menunjukkan apabila tingkat risiko kredit mengalami kenaikan sebesar 1 persen sementara variabel independen lainnya konstan maka profitabilitas akan mengalami penurunan sebesar 0,415 persen. Variabel risiko operasional $\left(\mathrm{X}_{3}\right)$ mempunyai koefisien $-0,219$ dengan arah negatif. Hal ini menunjukkan apabila tingkat risiko operasional mengalami kenaikan sebesar 1 persen sementara variabel independen lainnya konstan maka profitabilitas akan mengalami penurunan sebesar 0,219 persen.

\begin{tabular}{|c|c|c|c|c|c|c|}
\hline \multicolumn{7}{|c|}{$\begin{array}{c}\text { Tabel } 9 \\
\text { Uji t }\end{array}$} \\
\hline & \multirow{2}{*}{ Model } & \multicolumn{2}{|c|}{$\begin{array}{c}\text { Unstandardized } \\
\text { Coefficients }\end{array}$} & \multirow{2}{*}{$\begin{array}{c}\text { Standardized } \\
\text { Coefficients }\end{array}$} & \multirow{2}{*}{$T$} & \multirow{2}{*}{ Sig. } \\
\hline & & $B$ & $\begin{array}{c}\text { Std. } \\
\text { Error }\end{array}$ & & & \\
\hline \multirow{4}{*}{1} & (Constant) & 0,026 & 0,078 & & 0,338 & ,736 \\
\hline & LDR &, 364 & 0,087 &, 36 & 4,202 & 000 \\
\hline & NPL &,- 415 & 0,096 &,- 417 & $-4,33$ &, 000 \\
\hline & BOPO &,- 219 & 0,093 &,- 217 & $-2,367$ & 021 \\
\hline
\end{tabular}

Berdasarkan Tabel 9, dapat dilihat bahwa variabel LDR memiliki nilai t hitung yang lebih besar dari t tabel $(4,202>1,997)$ dengan nilai signifikansi 0,000 yang lebih kecil dari 0,05. Hasil ini menunjukan bahwa risiko likuiditas yang diwakili oleh LDR berpengaruh positif dan signifikan terhadap profitabilitas yang diwakili oleh ROA.

Variabel NPL memiliki nilai t hitung yang lebih kecil dari t tabel $(-4,33<1,997)$ dengan nilai signifikansi 0,000 yang lebih kecil dari 0,05. Hasil ini menunjukkan 
bahwa risiko kredit yang diwakili oleh NPL berpengaruh negatif dan signifikan terhadap profitabilitas yang diwakili oleh ROA.

Variabel BOPO memiliki nilai t hitung yang lebih kecil dari t tabel $(-2,367<$ 1,997) dengan nilai signifikansi 0,021 yang lebih kecil dari 0,05. Hasil ini menunjukkan bahwa risiko operasional yang diwakili oleh BOPO berpengaruh negatif dan signifikan terhadap profitabilitas yang diwakili oleh ROA.

\begin{tabular}{ccccccc}
\multicolumn{7}{c}{ Tabel 10 } \\
Uji F \\
\hline \multirow{2}{*}{ Model } & $\begin{array}{c}\text { Sum of } \\
\text { Squares }\end{array}$ & Df & $\begin{array}{c}\text { Mean } \\
\text { Square }\end{array}$ & F & Sig. \\
\hline & Regression & 41,749 & 3 & 13,916 & 33,707 &, 000 \\
1 & Residual & 26,423 & 64 & 0,413 & & \\
& Total & 68,172 & 67 & & & \\
\hline
\end{tabular}

Sumber: Data Diolah, 2017

Tabel 10 menunjukkan, berdasarkan hasil uji nilai signifikansi $\mathrm{F}$ adalah sebesar 0,000 yang lebih kecil dari $0,05(\mathrm{~F}<\alpha)$ yang berarti variabel independen berpengaruh signifikan secara serempak atau bersama-sama terhadap variabel dependen, sehingga penelitian ini dapat dikatakan memenuhi uji kelayakan model atau model penelitian dinyatakan layak digunakan sebagai model regresi.

Tabel 11

Koefisien Determinasi

\begin{tabular}{ccccc} 
Model & $\boldsymbol{R}$ & $\boldsymbol{R}$ Square & $\begin{array}{c}\text { Adjusted } \boldsymbol{R} \\
\text { Square }\end{array}$ & $\begin{array}{c}\text { Std. Error of the } \\
\text { Estimate }\end{array}$ \\
\hline 1 &, 783 &, 612 &, 594 & 0,64254301 \\
\hline
\end{tabular}

Sumber: Data Diolah, 2017 
Tabel 11 menunjukkan besarnya nilai adjusted $\mathrm{R}$ square adalah sebesar 0,594 yang artinya sebesar 59,4 persen variasi profitabilitas dipengaruhi oleh risiko likuiditas, risiko kredit, dan risiko operasional, sedangkan sisanya sebesar 40,6 persen dipengaruhi oleh faktor-faktor lain yang tidak dimasukkan kedalam model penelitian.

Berdasarkan hasil uji t, diketahui bahwa risiko likuiditas yang diwakili oleh LDR memiliki nilai t hitung yang lebih besar dari t tabel $(4,202>1,997)$ dengan nilai signifikansi 0,000. Hasil signifikansi tersebut menunjukkan bahwa taraf signifikansi LDR lebih kecil dari taraf $\alpha$ yaitu 0,05, sehingga dapat disimpulkan bahwa risiko likuiditas yang di wakili oleh LDR berpengaruh positif signifikan terhadap profitabilitas yang diwakili oleh ROA. Hasil tersebut menunjukkan bahwa hipotesis 1 yang menyatakan risiko likuiditas memiliki pengaruh positif signifikan terhadap profitabilitas diterima. Tingkat risiko likuiditas dari BPR di Kota Denpasar yang tinggi menunjukkan bahwa pembiayaan bank dalam bentuk penyaluran kredit juga tinggi sehingga akan meningkatkan profitabilitas. Sebaliknya apabila tingkat risiko likuiditas BPR di Kota Denpasar rendah menunjukkan bahwa bank tersebut memegang aset berupa kas yang besar sehingga kesempatan untuk memberikan pembiayaan berupa penyaluran kredit dalam rangka memaksimalkan pendapatan menjadi terbatas. Terbatasnya penyaluran dana pada BPR di Kota Denpasar akan menyebabkan terjadinya dana yang tidak produktif yang sebenarnya dapat dialokasikan dalam bentuk aset lain yang lebih produktif. Hasil penelitian ini sejalan dengan hasil penelitian sebelumnya yang dilakukan oleh Jumono et al. (2015), Prasetyo dan Darmayanti 
(2015), dan Abel and Roux (2016) yang menemukan bahwa risiko likuiditas berpengaruh positif dan signifikan terhadap profitabilitas (ROA) bank.

Berdasarkan hasil uji t, diketahui bahwa risiko kredit yang diwakili oleh NPL memiliki nilai t hitung yang lebih kecil dari t tabel $(-4,33<1,997)$ dengan nilai signifikansi 0,000. Hasil tersebut menunjukkan bahwa taraf signifikansi NPL lebih kecil dari taraf $\alpha$ yaitu 0,05 , sehingga dapat disimpulkan bahwa risiko kredit yang di wakili oleh NPL berpengaruh negatif signifikan terhadap profitabilitas yang diwakili oleh ROA. Hasil tersebut menunjukkan bahwa hipotesis 2 yang menyatakan risiko kredit memiliki pengaruh negatif signifikan terhadap profitabilitas diterima. Tingkat risiko kredit yang tinggi pada BPR di Kota Denpasar menunjukkan bahwa jumlah kredit macet yang terjadi pada bank tersebut juga tinggi, tingginya kredit macet yang terjadi menyebabkan pendapatan yang diterima oleh bank menurun. Sebaliknya apabila tingkat risiko kredit pada BPR di Kota Denpasar rendah menunjukkan bahwa jumlah kredit macet pada bank tersebut juga rendah sehingga pendapatan bank tersebut juga meningkat. Hasil penelitian ini didukung oleh penelitian sebelumnya yang dilakukan oleh Rahman et al. (2015), Abel and Roux (2016), Bhattarai (2016), Suryanto (2017) yang menyatakan bahwa risiko kredit berpengaruh negatif signifikan terhadap profitabilitas.

Berdasarkan hasil uji t, diketahui bahwa risiko operasional yang diwakili oleh BOPO memiliki nilai thitung yang lebih kecil dari t tabel $(-2,367<1,997)$ dengan nilai signifikansi 0,021. Hasil tersebut menunjukkan bahwa taraf signifikansi BOPO lebih 
kecil dari taraf $\alpha$ yaitu 0,05 , sehingga dapat disimpulkan bahwa risiko operasional yang di wakili oleh BOPO berpengaruh negatif signifikan terhadap profitabilitas yang diwakili oleh ROA. Hasil tersebut menunjukkan bahwa hipotesis 3 yang menyatakan risiko operasional memiliki pengaruh negatif signifikan terhadap profitabilitas diterima. Tingginya tingkat risiko operasional pada BPR di Kota Denpasar menunjukkan bahwa BPR di Kota Denpasar tidak mampu menekan biaya operasionalnya seefisien mungkin sehingga menyebabkan bank tersebut mengalami penurunan profitabilitas. Sebaliknya apabila tingkat risiko operasional yang terjadi pada BPR di Kota Denpasar rendah menunjukkan bahwa bank tersebut mampu mengelola biaya operasionalnya sehingga mampu meningkatkan profitabilitas. Hasil penelitian ini sejalan dengan penelitian sebelumnya yaitu penelitian yang dilakukan oleh Buchory (2015), Dewi dkk. (2015), dan Capriani dan Dana (2016) yang menyatakan bahwa risiko operasional memiliki pengaruh negatif signifikan terhadap profitabilitas.

Berdasarkan pembahasan, penelitian ini memberikan implikasi teoritis bahwa risiko likuiditas, risiko kredit dan risiko operasional mempunyai pengaruh yang signifikan terhadap profitabilitas Bank BPR di Kota Denpasar. Peningkatan atau penurunan dari risiko likuiditas, risiko kredit dan risiko operasional akan mempengaruhi besarnya tingkat profitabilitas yang didapat oleh bank. Hal ini menunjukkan bahwa risiko-risiko tersebut mempunyai peran yang penting bagi bank untuk meningkatkan tingkat profitabilitasnya. Sedangkan, implikasi praktis dari 
penelitian ini adalah selain mempunyai peran penting dalam meningkatkan profitabilitas, risiko-risiko tersebut juga dapat memberikan informasi dan masukan bagi Bank Perkreditan Rakyat (BPR) dan pihak-pihak lainnya agar dapat membuat keputusan yang tepat terkait dengan profitabilitas.

\section{SIMPULAN DAN SARAN}

Berdasarkan hasil penelitian serta pembahasan mengenai pengaruh risiko bank terhadap profitabilitas BPR di Kota Denpasar yang telah diuraikan pada sebelumnya, maka diperoleh simpulan sebagai berikut: 1) Risiko likuiditas berpengaruh positif dan signifikan terhadap profitabilitas. Hal ini menunjukkan apabila tingkat risiko likuiditas BPR di Kota Denpasar tinggi, maka pembiayaan berupa penyaluran kredit juga akan besar. Meningkatnya penyalurkan kredit yang dilakukan oleh Bank BPR di Kota Denpasar akan meningkatkan profitabilitas yang didapat bank tersebut. 2) Risiko kredit berpengaruh negatif dan signifikan terhadap profitabilitas. Hal ini menunjukkan bahwa apabila terjadi peningkatan kredit bermasalah pada BPR di Kota Denpasar maka

profitabilitas yang didapatkannya akan semakin menurun. 3) Risiko operasional berpengaruh negatif signifikan terhadap profitabilitas. Hal ini menunjukkan bahwa apabila biaya operasional BPR di Kota Denpasar meningkat maka profitabilitas yang didapatkan akan menurun.

Berdasarkan kesimpulan diatas maka saran yang dapat diberikan sebagai berikut: 1) Risiko likuiditas yang diwakili oleh LDR berpengaruh positif dan signifikan terhadap profitabilitas yang diwakili oleh ROA, maka disarankan kepada pihak BPR di 
Kota Denpasar untuk lebih menyalurkan kredit guna meningkatkan profitabilitasnya. Risiko kredit yang diwakili NPL berpengaruh negatif dan signifikan terhadap profitabilitas yang diwakili ROA, maka disarankan pihak BPR di Kota Denpasar agar berhati-hati dalam memberikan pinjaman pada nasabah agar tidak terjadi kredit macet. Risiko operasional yang diwakili oleh BOPO berpengaruh negatif dan signifikan terhadap profitabilitas yang diwakili ROA, maka disarankan kepada pihak BPR di Kota Denpasar untuk lebih menekan biaya operasionalnya agar keuntungan yang didapat menjadi lebih besar. 2) Peneliti selanjutnya sebaiknya menggunakan periode yang lebih lama lagi agar memperoleh hasil yang lebih baik lagi. Selain itu peneliti juga menyadari dalam penelitian ini memiliki keterbatasan penelitian yang hanya menganalisis pengaruh risiko perbankan sebagai variabel yang mempengaruhi profitabilitas bank padahal masih banyak faktor-faktor lain yang bisa mempengaruhi profitabilitas. Sehingga diharapkan penelitian selanjutnya bisa mengkaji faktor-faktor lain yang bisa mempengaruhi profitabilitas.

\section{REFRENSI}

Abdullah, Mohammad Nayeem and Jahan, Nusrat. 2014. The Impact of Liquidity on Profitability in Banking Sektor of Bangladesh: A Case of Chittagong Stock Exchange. EPRA International Journal Of Economi and Business Review, 2 (10), pp.17-22.

Abdullah, Thamrin. 2012. Bank dan Lembaga Keuangan. Jakarta: Rajawali Pers.

Abel, Sanderson and Roux, Pierre Le. 2016. Determinants of Banking Sector Profitability in Zimbabwe. International Journal of Economics and Financial Issues, 6 (3), pp.845-854. 
Alkhazaleh, Ayman Mansour and Almsafir, Mahmoud. 2014. Bank Specific Determinants of Profitability in Jordan. Journal of Advanced Social Research, 4 (10), pp.1-20.

Almadany, Khairunnisa. 2012. Pengaruh Loan To Deposit Ratio, Biaya Operasional Per Pendapatan Operasional dan Net Interest Margin Terhadap Profitabilitas Perusahaan Perbankan. Jurnal Riset Akuntansi dan Bisnis. 12 (2), hal.165-183.

Anam, A. Khoirul. 2013. Risiko Likuiditas dan Dampaknya Terhadap Kinerja Perbankan di Indonesia. Jurnal Dinamika Ekonomi, 10 (1), hal.1-16.

Arthesa, Ade dan Handiman, Edia. 2009. Bank dan Lembaga Keuangan Bukan Bank. Jakarta : Indeks.

Bank Indonesia. 2009. Peraturan Bank Indonesia No 11/25/PBI/2009 Tentang Perubahan Atas Peraturan Bank Indonesia nomor 5/8/PBI/2003 Tentang Penerapan Manajemen Risiko bagi Bank Umum. Jakarta : Bank Indonesia.

Bhattarai, Yuga Raj. 2016. Effect of Non-Performing Loan on the Profitability of Commercial Banks in Nepal. The International Journal Of Business \& Management, 4 (6), pp.435-442.

Buchory, Herry Achmad. 2015. Banking Profitability: How does the Credit Risk and Operational Efficiency Effect. Journal of Business and Management Sciences. 3 (4), pp.118-123.

Budisantoso, Totok dan Nuritomo. 2015. Bank dan Lembaga Keuangan Lain. Jakarta: Salemba Empat.

Capriani, Ni Wayan Wita dan Dana, I Made. 2016. Pengaruh Risiko Kredit Risiko Operasional dan Risiko Likuiditas Terhadap Profitabilitas BPR di Kota Denpasar. E-Jurnal Manajemen Unud, 5 (3), hal.1486-1512.

Dahiyat, Ahmad. 2016. Does Liquidity and Solvency Affect Banks Profitability? Evidence from Listed Banks in Jordan. International Journal of Academic Research in Accounting, Finance and Management Sciences. 6 (1), pp.35-40.

Dawood, Usman. 2014. Factors Impacting Profitability of Commercial Banks in Pakistan for The Period of (2009-2012). International Journal of Scientific and Research Publications, 4 (3), pp.1-7.

Dewi, Luh Eprima., Herawati, Nyoman Trisna dan Sulindawati, Luh Gede Erni. 2015. Analisis Pengaruh NIM, BOPO, LDR, dan NPL Terhadap Profitabilitas (Studi 
Kasus Pada Bank Umum Swasta Nasional Yang Terdaftar Pada Bursa Efek Indonesia Periode 2009-2013). E-Journal S1 Ak. Universitas Pendidikan Ganesha, 3 (1), hal.1-11.

Ghozali, Imam. 2011. Aplikasi Analisis Multivariate dengan Program SPSS. Semarang : Badan Penerbit Universitas Diponegoro.

Hendro, Tri dan Rahardja, Conny Tjandra. 2014. Bank dan Institusi Keuangan Non Bank Indonesia. Yogyakarta: UPP STIM YKPN

Herlina., Nugraha dan Purnamasari, Imas. 2016. Pengaruh Risiko Kredit Terhadap Profitabilitas (Studi Kasus Pada Bank Umum Swasta Nasional Devisa Tahun 2010-2014). Journal of Business Management and Enterpreneurship Education, 1 (1), hal.31-36.

Jha, Suvita and Hui, Xiaofeng. 2012. A Comparison of Financial Performance of Commercial Banks: A Case Study of Nepal. African Journal of Business Management, 6 (25), pp.7601-7611.

Jumono, Sapto., Achsani, Noer Azam., Hakim, Dedi Budiman and Firdaus, Muhamad. 2015. The Impacts of ALMA Primary Variables on Profitability An Empirical Study of Indonesian Banking. International Research Journal of Business Studies, 8 (1), pp.13-32.

Martono. 2002. Bank dan Lembaga Keuangan Lain, Edisi Pertama. Yogyakarta : Ekonisia.

Nugraheni, Peni dan Alam, Whinda Febrianti Iskandar. 2014. Pengaruh Risiko Likuiditas Terhadap Profitabilitas Pada Perbankan Syariah dan Konvensional di Indonesia. Jurnal Akuntansi \& Investasi, 15 (1), hal. 1-16.

Ogboi, Charles and Unuafe, Okaro Kenneth. 2013. Impact of Credit Risk Management and Capital Adequacy on the Financial Performance of Commercial Banks in Nigeria. Journal of Emerging Issues in Economics, Finance and Banking (JEIEFB) An Online International Monthly Journal, 2 (3), pp.703-717.

Oktaviantari, Luh Putu Eka dan Wiagustini, Ni Luh Putu. 2013. Pengaruh Tingkat Risiko Perbankan Terhadap Profitabilitas pada BPR di Kabupaten Badung. EJournal Manajemen Universitas Udayana, 2 (12), hal. 1617-1633.

Pamularsih, Diyah. 2015. Pengaruh LDR, NPL, NIM, BOPO, CAR dan Suku Bunga Terhadap Profitabilitas pada Sektor Perbankan yang Terdaftar di Bursa Efek 
Indonesia Periode Tahun 2009-2013. Jurnal Ilmiah Mahasiswa S1 Akuntansi Universitas Pandanaran, 1 (1), 1-20.

Prasetyo, Dwi Agung dan Darmayanti, Ni Putu Ayu. 2015. Pengaruh Risiko Kredit, Likuiditas, Kecukupan Modal, dan Efisiensi Operasional Terhadap Profitabilitas pada PT BPD Bali. E-Jurnal Manajemen Unud, 4 (9), hal. 25902617.

Putri, Fifit Syaiful. 2013. Pengaruh Risiko Kredit dan Tingkat Kecukupan Modal Terhadap Tingkat Profitabilitas pada Perusahaan Perbankan yang Terdaftar di Bursa Efek Indonesia. Skripsi Sarjana Program Studi Akuntansi Fakultas Ekonomi Universitas Negeri Padang, Sumatra Barat.

Rahman, Mohammad Morshedur., Hamid, Md. Kowsar and Khan, Md. Abdul Mannan. 2015. Determinants of Bank Profitability: Empirical Evidence from Bangladesh. International Journal of Business and Management, 10 (8), pp.135-150.

Ramadanti, Fani dan Meiranto, Wahyu. 2015. Analisis Pengaruh Risiko Likuiditas Terhadap Profitabilitas Perusahaan Perbankan di Indonesia. Diponegoro Journal of Accounting, 4 (2), hal. 1-10.

Sudiyanto, Bambang dan Fatmawati, Asih. 2013. Pengaruh Risiko Kredit dan Efisiensi Operasional Terhadap Kinerja Bank (Studi Empirik pada Bank yang Terdaftar di Bursa Efek Indonesia). Jurnal Organisasi dan Manajemen, 9 (1), hal.73-86.

Suryanto. 2017. Determinats of Profitability in Commercial Banks of Indonesia an Empirical Study. International Journal of Business and Management Review, 5 (1), pp.1-11.

Syafi'I, Muhammad Fahrul Rozi. 2016. Pengaruh Risiko Kredit, Risiko Pasar, Risiko Operasional dan Risiko Likuidias Terhadap Profitabilitas Perbankan (Studi Kasus Pada Bank Yang Terdaftar Di Bursa Efek Indonesia Periode 2010-2014). Skripsi Sarjana Program Pascasarjana Universitas Pasundan, Bandung.

Triandaru, Sigit dan Budisantoso, Totok. 2009. Bank dan Lembaga Keuangan Lain, Edisi 2. Jakarta: Salemba Empat.

Wiagustini, Luh Putu. 2010. Dasar-Dasar Manajemen Keuangan. Denpasar: Udayana University Press.

www.bi.go.id diakses pada tanggal 10 Juli 2017. 